of industries to the Government of Travancore and produced for that Government a monumental "Survey" of the industrial possibilities of the province.

His sound judgment and acute perception of essentials in technological and industrial matters led to many calls upon him by various Indian Provincial Governments, and his work for these is embodied in more than fifty bulletins and papers on chemical and allied industries for State Departments and other official bodies. Dr. Barker, with his wife, whom he had married in 1915 before he sailed from England, threw himself wholeheartedly into all the activities of his surroundings, and served for some time as an officer of one of the local regiments. $\mathrm{He}$ was, for a period, vice-principal of the Maharajah's College at Trivandrum (University of Madras) and took an active part in its development.

In 1921 , a breakdown in health forced Barker to return to England, and he began to suffer from the deafness which, in later years, became a severe handicap to all his activities. On his arrival in this country, he served for a time as principal assistant in the Research Department of Woolwich Arsenal. In 1926, he took up what was to be one of the great successes of his career-the directorship of the Wool Industries Research Association in Leeds. His brilliant work in this post, his devising of new processes and improvement in old ones, his invention of instruments and methods of testing, his work in organizing and compacting manufacture, resulted in notable progress in this fundamental industry, and established the Association as an indispensable factor in the development of sheep breeding and rearing and the improvement of the quality of the wool fibre throughout the British Empire. During this period also he worked in the closest association with and for the (now defunct) Empire Marketing Board, for which he examined many possibilities in the utilization of various fibres produced in different parts of the Empire. For this work he was awarded the O.B.E.

In 1934 he was invited to act as scientific adviser to the Indian Jute Mills Association, a position which he held to the time of his death. He visited India in 1935 and again in 1938 to establish and extend laboratories and supervise research and development schemes on behalf of the jute industry, and, on his return, he set up similar laboratories in Great Britain, supplementing and controlling the work in Calcutta. In this industry, as in the case of wool, he was responsible for rapid and useful progress, until the outbreak of war gave an already busy life still more work to be undertaken. He was appointed to various official advisory posts chiefly connected with the use of textiles and fibres in the war effort, and he was never lacking in suggestion and in the organization of inquiry whenever problems were encountered in which these products could be of use. His increased work caused him to suffer still more from deafness and from general ill-health until, in the course of completing an official journey to the north, he collapsed and shortly thereafter passed away.

Dr. Barker was a prodigious worker with an extraordinary memory for unusual items of information likely to be of use in his researches, and an energetic, cheerful and loyal colleague. He covered a wider range of scientific and industrial investigation during his life than is given to most men to achieve, and his success in what he undertook was recognized by the many honours conferred upon him and by membership of a large number of scientific and technical societies and committees, both at home and abroad. His output of written contributions to knowledge includes two monumental works on "Wool", and treatises on "Coir", "Sisal" and "Jute", in all of which fibres he was the world's foremost authority. Besides these works, he has to his name more than two hundred shorter papers, brochures and reviews of a less comprehensive character.

His death at this time, when his knowledge and experience were of so much value to the national war effort, is a grievous loss, and the thought that his passing was due solely to the intensity of his striving to help, is a tragedy. He leaves a widow, but no family.

\section{Prof. Ludwig Aschoff}

Prof. Ludwig Aschoff, the eminent German pathologist and medical historian, whose death at Freiburg im Breisgar was recently announced, was born in Berlin on January 10, 1866. He received his medical education at Bonn, Strassburg and Berlin and qualified at Bonn in 1889. After serving as assistant in Recklinghausen's Pathological Institute during 1891-1893 and at the pathological institute at Göttingen from 1893 until 1903, he was appointed professor of morbid anatomy at Marburg and at Freiburg im Breisgau three years later. His principal work was a system of morbid anatomy, of which he was editor and to which he contributed the articles on disorders of the circulation, inflammation, the heart and pericardium, urinary system, female sexual apparatus, and the digestive system. The eighth edition appeared in 1936. His other publications included works on appendicitis, cholelithiasis, thrombosis, scurvy, and a history of medicine in tabular form, of which the third edition in collaboration with Prof. Paul Diepgen was published in 1936. He was also editor of Beiträge zur pathologischen Anatomie, und zur allgemeinen Pathologie and co-editor of Veröffentlichwngen aus der (Kriegs-) Gewerbe- und Konstitutionspathologie. Aschoff's name is attached to an organ in the paradidymis and paroophoron, rheumatic nodules in the myocardium and lungs and with that of Tawara to the atrioventricular node in the heart.

J. D. Rolleston.

WE regret to announce the following deaths:

Mr. F. W. Clifford, librarian of the Chemical Society, on September 21.

Prof. E. Fawcett, emeritus professor of anatomy in the University of Bristol, on September 22, aged seventy-five.

Prof. P. A. Hillhouse, professor of naval architecture in the University of Glasgow since 1921, on September 28, aged seventy-three.

Prof. W. J. G. Land, emeritus professor of botany in the University of Chicago, known for his work on tropical plants, on August 1, aged seventy-six.

Dr. Henry G. Knight, chief of the Bureau of Chemistry and Soils of the U.S. Department of Agriculture, on July 13, aged sixty-three.

Prof. David Waterston, Bute professor of anatomy in the University of St. Andrews, on September 4, aged seventy-one.

Prof. H. D. Wright, professor of bacteriology in the University of Liverpool and City bacteriologist to the Liverpool Corporation, on September 9, aged fifty-one. 